\title{
Communication Arising from Relationship Orientation: The Indicator of Keeping Business Cooperation
}

\author{
Jianhua $\mathrm{Ye}^{*}$ and Mingli Zhang
}

School of Economics and Management, Beihang University, Beijing 100191, China

\begin{abstract}
From the pespective of relationship orientation, this paper focuses in studying how communication inluences business cooperation. Firstly, this paper has a review of relevant theories of communication, trust and value co-creation, and proposes model assumes. Next, this paper descripts the relevant research methods, including the background, data collection, quantitative research methods. Finally, the significance and limitations of this research, further research direction are discussed.
\end{abstract}

Keywords: Relationship orientation, communication, trust, value co-creation.

\section{INTRODUCTION}

Recently, the relationship between suppliers and their customers is gradually changing: customers will participate in the suppliers' products and service in the designing and production process, and suppliers will actively help customers to refine and improve their products and service [1]. Such close cooperation of suppliers and customers makes that the importance of physical products transaction has gradually been replaced by intangible service, intangible resources, such as skills and technology, replace tangible assets to become the core competitiveness of enterprises. For example, in the building process of Cloud Resource Management Platform of China Unicom, Microsoft and Dell give technical support for architecture designing, operations and maintenance, meanwhile, China Unicom helps them to improve server products and virtualization technologies through feeding back the problems encountered during the process of Platform operations, which can enhance market competitiveness of Microsoft and Dell. It is extremely difficult to regulate the behaviors of suppliers and customers by the contract simply, changes of cooperation lead enterprises border to be indistinct increasingly [2]. Accordingly, some scholars promise that companies should deal with the increasingly complex partnerships by relationship orientation, so both of the partnerships can get more value in the dynamic process of cooperation [3].

Gradually Economic behaviors among enterprises shift from transaction orientation to relationship orientation, many scholars have conducted thorough theoretical studies [4]. Traditional transaction marketing views communication mechanism as an important process of suppliers

*Address correspondence to this author at the School of Economics and Management, Beihang University, Beijing 100191, China;

E-mail: farmerblank@sina.com persuading customers to buy their products [4], which reflects a one-way inform. For relationship marketing, communication can be made by either of partnerships, suppliers or customers are possible, and communication process is two-way. This bi-directional, positive communication can promote partners to perceive value more sensibly, and then affect the process of entire value generation, although communication does not produce value [5]. In marketing activities of relationship orientation, suppliers and customers establish, consolidate and develop the long-term benefits to both, through approving communicating with each other in many ways [6].

It is easy to establish a trust relationship of supplier and customer through frequent communication behavior [7] (Sergio, 2012), such trust relationship can help partners to cocreate value by the orientation of long-term relationship [8]. At the same time, communication plays a key role for intangible resource transfer, such as knowledge and technology, which has important implications for the value creation process of suppliers and customers [9]. Furthermore, communication can make suppliers and customers establish and develop relationship with confidence, and will take a proactive approach to facilitate the process of value creating. Communicate impacts multiple factors that can affect the process of value creation, which also help it become one of the key factors affecting value creation [10].

In previous studies of value creation, although many scholars have referred to an obvious link between communication and value creation in relationship marketing [11], even, corporate communication strategy can affect the perception of relationship value and the future development of relationship. But very unfortunately, there are few empirical researches that communication impacts on the process of value creation. 


\section{LITERATURE REVIEW AND DEVELOPMENT OF HYPOTHESES}

\subsection{Relationship Orientation}

The paradigmatic shift from transaction orientation to relationship orientation and the resulting change of focus from products and exchange to service and relationships are well recognised in marketing [4]. Day (2000) uses the term relationship orientation to describe the selling firm's culture or climate. That is to say, the relationship orientation can be regarded as a successful business philosophy and as a culture of organization, which makes buyer and seller relationship as a central idea of strategic and business ideas of a company [12] (Morgan and Hunt, 1994).

The need for relationship orientation has been recognized in sales and marketing research [13], which results in the modification of the traditional selling process to make the selling process more relationship oriented [14]. In many industries, there is a transition towards closer relationships and bigger purchasing entities taking place, which adds to the importance of relationship orientation in purchasing.

Adaptation is one of the characteristic phenomena associated with relationships and relationship orientation [15]. What clearly increases adaptive behavior is the supplier's managerial transactional-relational business approach: relationship orientation increases adaptive behavior, whereas transaction orientation decreases it [16]. In fact, the best adaptation to the supplier needs to communicate with the buyer, that is to say, the act of communication represents the supplier's best attempt to adapt the specific situation.

Indeed, as Bullen, LeFave and Selig (2010, p. 155) state, relationship management is actually about coordinating interactions in a way that further creates trust, interdependence and mutual value [17].

\subsection{Communication}

According to Grönroos (2004), relationship orientation including planned communication and interaction processes - demands so much more effort that the entire strategy should consistently aim to create sufficient value to the customer. Wilson takes the value creation as a need for time to develop trust and communication processes for partners to develop their mutual benefits results from interaction. Better communication and more information may lead to improved forecasting, possibly through reduced uncertainty and better problem solving.

A number of scholars have studied the role of communication with regard to relationship development [19] (Buttle and Biggemann, 2009). Grönroos (2004) believes that in order for relationship marketing to succeed, communications must be utilized to support the establishment, maintenance and enhancement of relationship with customers [18]. It is necessary to achieve the benefits of cooperation for effective communication between partners. In fact, it's difficult to develop or maintain a special business relationship if there is lack of communication and mutual understanding [20].

Drawing on the relational view of strategic management, Paulraj, Lado \& Chen (2008) conceptualized interorganizational communication as a relational competency, which is critical to achieving strategic advantage [21]. Communication among suppliers and buyers in the supply chain fosters inter-organizational learning, knowledge development, trust and commitment, reduced transactions costs and enhanced transaction value [22]. Collaborative communication is particularly appropriate for relational, enduring buyer-seller relationships based on mutually beneficial, supportive outcomes and has frequency, bi-directionality, formality, and content facets [23].

Recent results show that the results of the successful communication are customer perceived value, from the increase in the relationship between two parties of the buyer and the seller [24]. Better communication also leads to greater customer loyalty [25]. So, we propose:

H1: Relationship Orientation is positively related to communication.

\subsection{Trust}

Trust was beginning to occupy a more central position, particularly filtering through from psychology, sociology, theories of organizational behavior [26] and some parts of economics. Business marketing research accounts trust for describing relationship structure [27]. Trust is a key regulator of relationship, which facilitates the increase of relational commitment, resulting in the continuity of enterprise, reducing the vulnerability of perceived to greater supplier behavior, and uncertainty. It is easy to say that trust is treated as foundational in forming and maintaining relationships.

While both sides trust in the relationship they may invest resources and efforts in committing and cooperating each other mutually. Williamson (1985) pointed out that in the same circumstances, the exchange relationship believe trust could manage pressure and show greater adaptability. Ouchi [1980] believe that trust, generated from the perception of long-term equity within the relationship, is essential for ongoing charitable exchanges. The relationship between longterm equity is essential for continuing charitable exchanges. The main function of trust is to act as a governance mechanism which can eliminate opportunism [28] without opportunistic threats, the trust companies set is not mandatory. Trust in relationships requires a common belief that partners will not act opportunistically [29], whereas manifest opportunistic behavior likely degrades trust and thus harms relationship quality. Relationships built on commitment and trust provide shelter from opportunistic threats [30] (Gregoire, 
Tripp, and Legoux 2009) and facilitate cooperation, enhancing financial performance and other positive outcomes such as market penetration (Morgan and Hunt 1994).

Pruitt (1981) showed that the trust (i.e., believe that the party is reliable, can in the exchange to fulfill the obligations) is a cooperation company hopes to highly correlated. Trust is conducive to more effective and efficient relationships, which directly affects the prognosis, so the satisfaction degree is achieved [31], and the degree of commitment of the relationship customers. Denize and Young (2007) regard the positive effects of information exchange norms on trust between the parties [32].

In the theory of transaction cost economics, trust is the economic value, reduce transaction costs, negotiate costs, monitor and monitor the cost and uncertainty, information sharing as an alternative to control [33] (Dyer and Chu, 2003). Dyer and Chu found that relationships with high levels of trust were associated with substantially lower costs and, since trust encourages the sharing of resources, it actually adds value to the relationship. In the research of operational management, Trust is the flexibility of performance improvement in supply chain, and the positive results of response speed are significantly predicted, and the cost is reduced. So, we propose:

$\mathrm{H} 21$ : Communication is positively related to trust.

\subsection{Joint Initiative}

Based on the method of the first step is to ford and McDowell (1999), which includes joint actions for identifying and verifying each relationship [34]. The Global Supply Chain Forum (GSCF) framework put more emphasis on the buyer-supplier relationships that are formed in a supply chain context. The GSCF advocates for the integration of eight key business processes (customer relationship management, supplier relationship management, customer service management, demand management, order management, production process, product development and commercialization, and return management), which emphasizes the relationship management and cross functional role and establish key members of the supply chain through the improvement of the value of economic activity. In contrast, the results obtained by Clark (1989), King and Peneleskey (1992), and Eisenhardt and Tabrizi (1995) show a negative impact on development time, which was attributed to the difficulty of coordinating joint initiatives [35]. We put forward a financial performance in the buyer - supplier relationships of joint action, in a single financial index value co-creation of quantitative methods: revenues minus and the relationship between planned and its related cost can be avoided.

Value is the interaction between customer perception and production, so only from the joint activities of suppliers and customers (ball joint) or from a single customer activity [36] (customer sphere; Grönroos and Voima 2012).

Customers have more knowledge about this problem, and more information about the supplier to the solution; their cooperation should focus on the common development of the solution.
In order to enhance the knowledge, customers participate in joint value creation and query the service provider for more details or refer to other service providers [37]. Kilduff, Mehra, and Dunn (2011) contend that joint problem solving, across organizational boundaries, leads to new, shared knowledge, and increased innovation [38]. This customer focused collaboration of knowledge development to jointly solve problems is a fluid, flexible, continually changing process with each problem solver bringing a different set of experiences, knowledge, skills, and perspectives. So, we propose:

H22: Communication is positively related to joint initiative.

H31: Trust is positively related to joint initiative.

\subsection{Knowledge}

In a study of relational purchasing and innovation, Modi and Mabert (2010) found that close communication, information sharing, and joint problem solving exposed the buying organization to different approaches and perspectives, leading to more flexible thinking and enhanced breadth of knowledge. The knowledge gained in partner relationship is probably the most valuable partner output but is probably the most difficult to measure. Badaracco points, "An organization to obtain the knowledge of the embedded into another program, it must form a complex, close relationship." Embedded knowledge acquisition has a huge firm value. If krnart can remission the embedded knowledge that the operation of the power distribution system with wal-mart, kmart can obtain their distribution system greatly reduce the cost.

Flint and Mentzer (2006) argues that knowledge in a number of enterprise cooperation means that the supplier value is rarely final offer [39]. The authors point out that the value proposition of the supplier and the customer participate in the dialogue and cooperation with the emergency, and then considers the amendment to the satisfaction of both parties.

Namely, before the recommended value chain partners are a collection of exchange or coordinate their Shared knowledge. Also in management, the Resource Based View (RBV) theory of the firm suggests that firms orchestrate their resources (particularly knowledge and skills) to create a competitive advantage for both the supplier and other supply chain members [40]. The dynamic capabilities literature adopts a process orientation to continuous knowledge development through supply chain networks and social capital [41]. So, we propose:

$\mathrm{H} 23$ : Communication is positively related to knowledge transaction.

H32: Trust is positively related to knowledge transaction.

\subsection{Value Co-creation}

Value co-creation, it is a new kind of business and innovation paradigm described as personalized customers and 


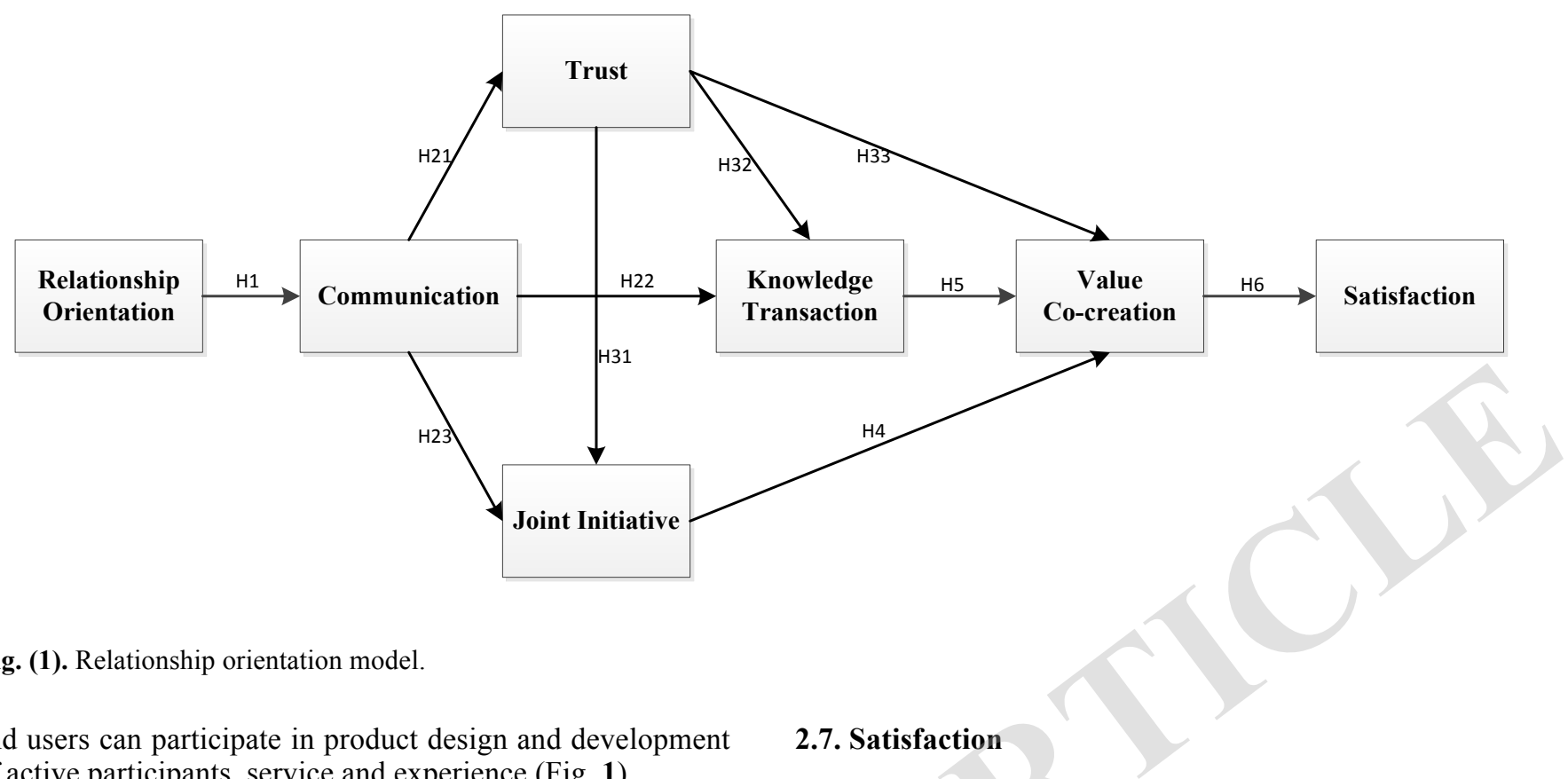

of active participants, service and experience (Fig. 1).

The existing value co-create theory studies more concentrate in service-oriented logic, and the research directions focus on: Work together to create customer dream [42]; meet the expectations [43]; a - generation cost function model [44]; supply chain and value chain management [45]; cross functional process [46]; and marketing strategy of the effectiveness and efficiency of operations [47].

In co-creating value, researchers put forward that the enterprise did not provide real value, and is simply the value proposition [48], this is the customer decision value, together with the enterprise to create it. Therefore, the product of a company is simply the value realization of until customers achieve common creation and gain an advantage.

Most studies have explored such as interactive relationships, mutual benefit, common value creation, dual direction and customer orientation. The value co-creation is also described as "autonomous, cooperative, and conversational interactions" [49].

In the case of these interactive dialogues, when both parties are active in a learning process, the perception and behavior of each person is influenced (Ballantyne and Varey, 2006). In the process of interactions, suppliers and customers are both value co- creation persons. So, we propose:

H33: Trust is the positive correlation of the value cocreation.

H4: Joint initiative is the positive correlation of the value co-creation.

H5: Knowledge transaction is the positive correlation of the value co-creation.
The importance of customer satisfaction is to maintain a healthy customer relationship. Customer satisfaction also provides an important linkage, purchase intention in the future [50].

Customer satisfaction can make the two members to stay in a stable relationship, and future exchanges due to positive interactive experience [51].

Now, customer satisfaction is customer oriented business practices still indispensable cornerstone in many companies operate in different industries [52], can be thought of as the essence of success in the highly competitive business world [53] described relationship satisfaction as a positive emotional state from the appraisal of various aspects of a working relationship [54].

Specifically, Wilson and Jantrania (1995) define satisfaction in terms of performance and the degree to which business dealings meet the expectations of the partner [55]. So, we propose:

H6: Value co-creation is positively related to satisfaction.

\section{METHODS}

\subsection{Sample and Data Collection}

A large-size company in China agreed to assist with data collection for this research, because most of the purchasing and technical experts are our schoolmates, and keep close relations with our laboratory. The involved enterprises are distributed in the industries of electronics, electricity, industrial control and aeronautics, which are quite representative. Age of respondents is between 34 and 57, the average age is 38.4. Work experience is between 8 and 30 , the average 


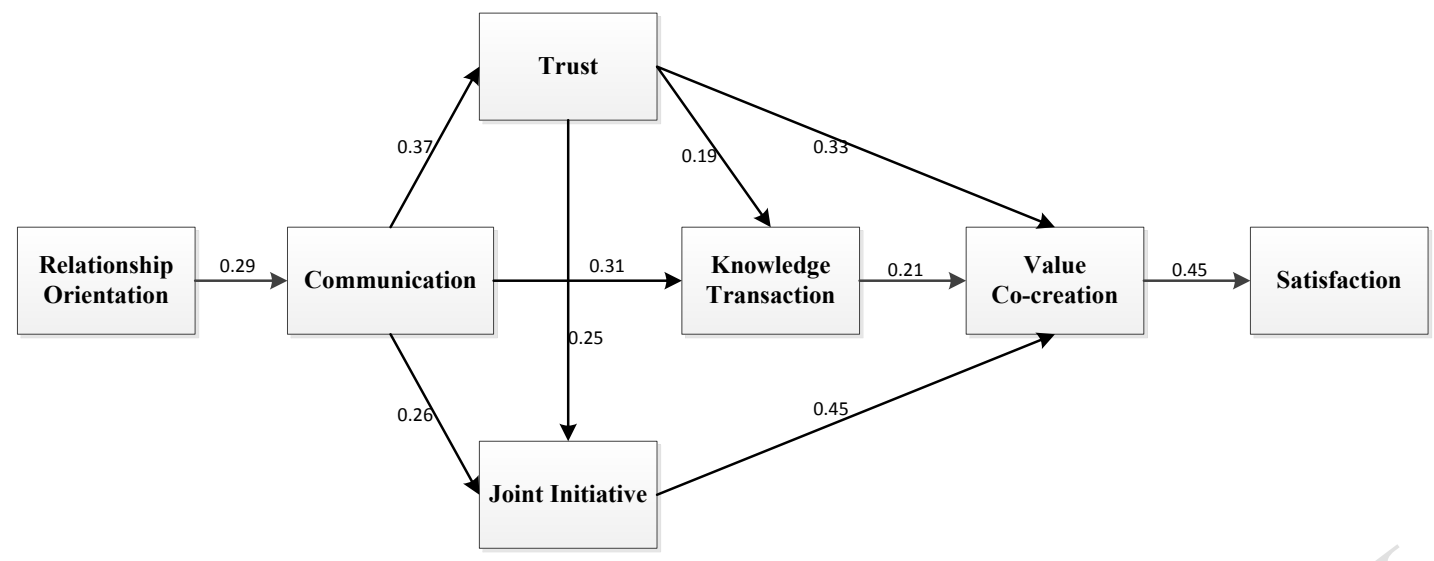

Fig. (2). Structural model results.

Table 1. Measurement model results.

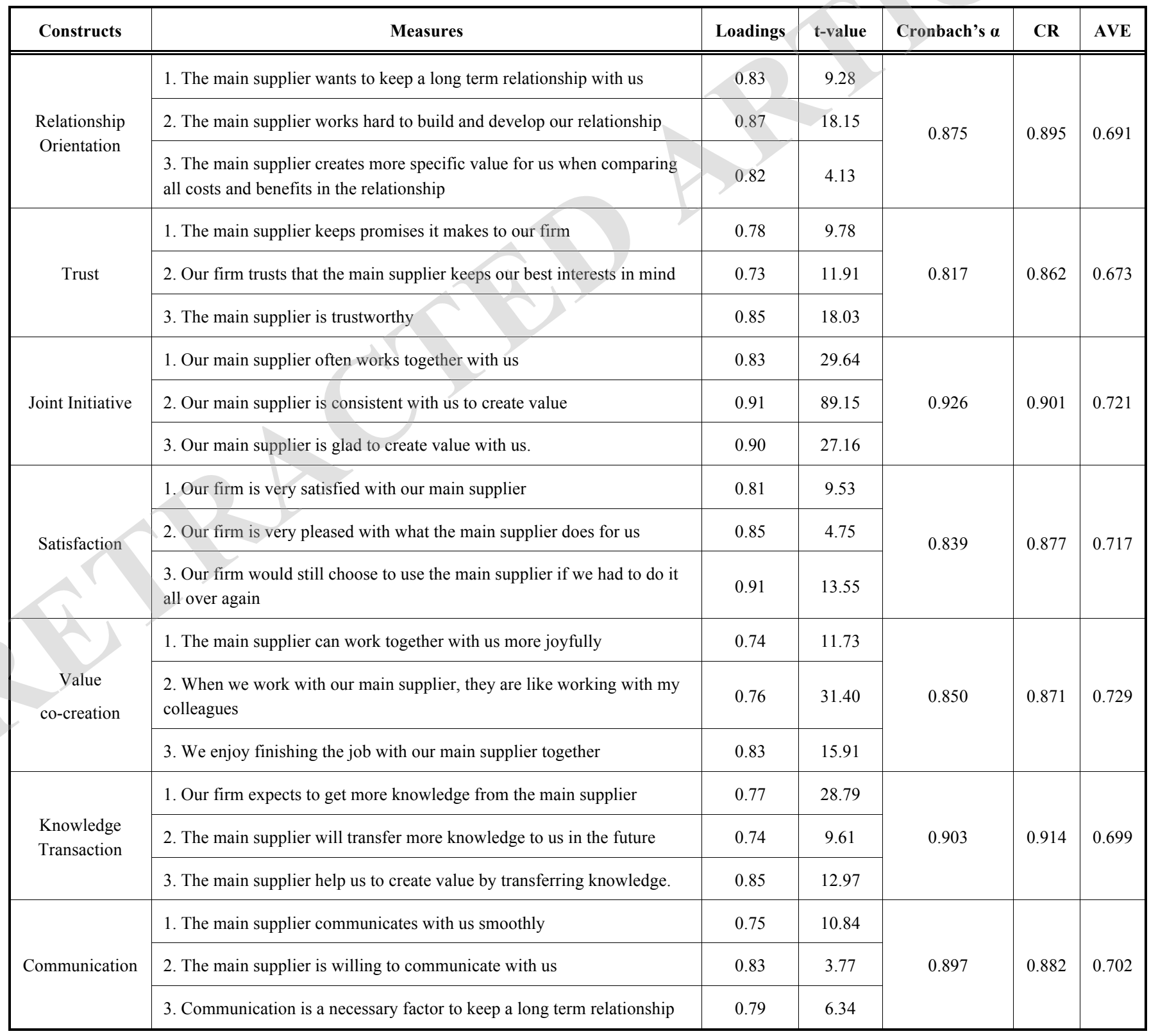


Table 2. Correlations and standard errors.

\begin{tabular}{|c|c|c|c|c|c|c|}
\hline & $\mathbf{1}$ & $\mathbf{2}$ & $\mathbf{3}$ & $\mathbf{4}$ & $\mathbf{5}$ & $\mathbf{6}$ \\
\hline \hline Relationship Orientation & 1 & & & & & \\
\hline Communication & $0.89(0.03)$ & 1 & & & & \\
\hline Trust & $0.92(0.02)$ & $0.85(0.02)$ & 1 & & & \\
\hline Joint Initiative & $0.87(0.02)$ & $0.95(0.02)$ & $0.83(0.02)$ & 1 & & \\
\hline Knowledge Transaction & $0.83(0.02)$ & $0.86(0.03)$ & $0.86(0.02)$ & $0.95(0.02)$ & & \\
\hline Value & $0.85(0.02)$ & $0.91(0.02)$ & $0.91(0.02)$ & $0.84(0.02)$ & $0.85(0.03)$ & 1 \\
\hline co-creation & $0.91(0.02)$ & $0.92(0.02)$ & $0.93(0.01)$ & $0.86(0.02)$ & $0.86(0.02)$ & $0.87(0.02)$ \\
\hline Satisfaction & & & 1 \\
\hline
\end{tabular}

work experience is 13.9. Influence of purchase decisions of respondents is measured by 7 Likert scale table, and the average is 5.95 .

The formal investigation was conducted during September and December in 2013. We employed students in Beihang University survey the related enterprises. We contacted 362 enterprises, and finally obtained 271 cases with valid information. The questionnaire recovery rate is $74.86 \%$.

\subsection{Measures}

All measures have been adopted from previous studies. In all, 21 items capture each elements (relationship orientation, communication, trust, joint initiative, knowledge transaction, value co-creation and satisfaction). The measurements are on account of Ulaga and Eggert (2006), Payne et al. (2008), Shekhar and Gupta (2008), Goala (2003), Jap (2001), Williamson (2005) respectively. We revise the measurements according to our industry background. The final questionnaire contains 21 items. All of the items is to use a 7 point scale measurement $(1=$ "strongly opposes" and 7 = "strongly agree").

\section{ANALYSIS AND RESULTS}

\subsection{Construct Validity}

The proposed step is guaranteed by Anderson and Gerbing(1988) to ensure adequate measurement and structural model. Composite reliabilities (CR) and averaged variances extracted (AVE) are shown in Table 1. The composite reliability of indicators of each construct is acceptable, ranging from 0.817 for corporate reputation to 0.926 for customer trust. Average variances extracted (AVE) are all above the recommended 0.5 level (Fornell and Larcker, 1981).

Additionally, all variables loaded significantly on the respective latent constructs $(\mathrm{p}<0.001)$ with the values ranging from 0.73 to 0.91 . Thus, the convergent validity was confirmed. The confidence interval ( \pm two standard errors) around the correlation estimate between any two latent variables does not include 1.0 (See Table 2), providing support for the discriminant validity.

\subsection{Hypotheses Testing}

The analysis proceeds to examine the structural model. A LISREL procedure was used to estimate the model. The overall model fit (chi-square $=398.26$, d.f. $=187, \mathrm{CFI}=0.93$, $\mathrm{NFI}=0.94, \mathrm{NNFI}=0.96, \mathrm{IFI}=0.97, \mathrm{GFI}=0.89, \mathrm{AGFI}=0.87$, RMSEA $=0.093$ ) provides an acceptable fit of the data.

Table 3 and Fig. (2) show the structural model results. The results show that relationship orientation is significantly related to communication $(\beta=0.29, \mathrm{t}=4.238)$, which supports H1. Communication is significantly related to trust $(\beta=0.37$, $\mathrm{t}=2.689)$, knowledge transaction $(\beta=0.31, \mathrm{t}=5.917)$ and joint initiative $(\beta=0.26, \mathrm{t}=3.656)$ are significant, $\mathrm{H} 21, \mathrm{H} 22$ and $\mathrm{H} 23$ are supported. Trust is significantly associated with joint initiative $(\beta=0.25, \mathrm{t}=4.192)$, knowledge transaction $(\beta=0.19, \mathrm{t}=5.065)$ and value co-creation $(\beta=0.33, \mathrm{t}=4.732)$, thus $\mathrm{H} 31, \mathrm{H} 32$ and $\mathrm{H} 33$ is supported. Joint initiative is significantly associated with value co-creation $(\beta=0.45, \mathrm{t}=2.473)$ which supports $\mathrm{H} 4$, and knowledge transaction is significantly related to value co-creation $(\beta=0.21, \mathrm{t}=4.198)$, which supports H5. At last, value co-creation is found to be associated with Satifaction $(\beta=0.45, t=3.714)$. So, all of our hypotheses are supported.

\section{CONCLUSION}

From the perspective of relationship orientation, smooth communication can raise the level of trust, and promote the development of relationship. The influences of joint initiative and knowledge transaction in value co-creation is proved positive. The result of value co-creation between supplier and customer leads satisfaction, thus, builds a long term relationship. 
Table 3. Hypotheses testing results.

\begin{tabular}{|c|c|c|c|c|}
\hline & Path & Coefficient & t-value & Estimate Result \\
\hline \hline H1 & Relationship Orientation $\rightarrow$ Communication & 0.29 & $4.238^{* * *}$ & Supported \\
\hline H21 & Communication $\rightarrow$ Trust & 0.37 & $2.689 * *$ & Supported \\
\hline H22 & Communication $\rightarrow$ Joint Initiative & 0.31 & $5.917 * * *$ & Supported \\
\hline H23 & Communication $\rightarrow$ Knowledge Transaction & 0.26 & $3.656^{* * *}$ & Supported \\
\hline H31 & Trust $\rightarrow$ Joint Initiative & 0.25 & $4.192^{* * *}$ & Supported \\
\hline H32 & Trust $\rightarrow$ Knowledge Transaction & 0.19 & $5.065^{* * *}$ & Supported \\
\hline H33 & Trust $\rightarrow$ Value co-creation & 0.33 & $4.732^{* * *}$ & Supported \\
\hline H4 & Joint Initiative $\rightarrow$ Value co-creation & 0.45 & $2.473 * *$ & Supported \\
\hline H5 & Knowledge Transaction $\rightarrow$ Value co-creation & 0.21 & $4.198^{* * *}$ & Supported \\
\hline H6 & Value co-creation $\rightarrow$ Satisfaction & 0.45 & $3.714 * * *$ & Supported \\
\hline
\end{tabular}

\section{CONFLICT OF INTEREST}

The authors confirm that this article content has no conflicts of interest.

\section{ACKNOWLEDGEMENTS}

The author thanks the National Natural Science Foundation of China for funding (70972002).

\section{REFERENCES}

[1] H. Löbler, "Service-dominant networks An evolution from the service-dominant logic perspective", Journal of Service Management, vol. 24, no. 4, pp. 420-434, 2013.

[2] W. J. L. Elving, "The role of communication in organisational change", Corporate Communications: An International Journal, vol. 10, no. 2, pp. 129-138, 2005.

[3] H. Winklhofer, A. Pressey, and N. Tzokas, "A cultural perspective of relationship orientation: using organisational culture to support a supply relationship orientation", Journal of Marketing Management, vol. 22, pp. 169-194, 2006.

[4] S. L. Vargo, and R. F. Lusch, "Evolving to a new dominant logic for marketing," Journal of Marketing, vol. 68, no. 1, pp.1-17, 2004.

[5] B. David, P. Frow, R.J. Varey, and A. Payne, "Value propositions as communication practice: Taking a wider view," Industrial Marketing Management, vol. 40, pp. 202-211, 2011.

[6] P.R. Davis, and P. Love, "Alliance contracting: Adding value through relationship development," Engineering, Construction and Architectural Management, vol. 18, no. 5, pp.1-22, 2011.

[7] S. Biggemann, "The essential role of information sharing in relationship development", Journal of Business \& Industrial Marketing, vol. 27, no. 7, pp. 521-526, 2012.

[8] D. Corsten, and N. Kumar, "Do suppliers benefit from collaborative relationships with large retailers? An empirical investigation of efficient consumer response adoption," Journal of Marketing, vol. 69 , no. 3, pp. 80-94, 2005

[9] F. von Corswant, and C. Tunälv, "Coordinating customers and proactive suppliers A case study of supplier collaboration in product development," Journal of Engineering, Technology and Management, vol. 19, pp. 249-261, 2002.

[10] C.V. Bullen, R. Lefave, and G.J. Selig, "Implementing strategic sourcing: A manager's guide to world class best practices," NL: Van Haren Publishing, 2010.
[11] S. Biggemann, "The essential role of information sharing in relationship development", Journal of Business \& Industrial Marketing, vol. 27, no. 7, pp. 521-526, 2012.

[12] R.M. Morgan, and S.D. Hunt, "The commitment-trust theory of relationship marketing", Journal of Marketing, vol. 58, no. 3, pp. 20-38, 1994.

[13] J. N. Sheth, and A. Sharma, "The impact of the product to service shift in industrial markets and the evolution of the sales organization," Industrial Marketing Management, vol. 37, no.3, pp. 260269, 2008.

[14] W. C. Moncrief, and G. W. Marshall, "The evolution of the seven steps of selling," Industrial Marketing Management, vol. 34, no.1, pp. 13-22, 2005.

[15] B. D. Ross, P. W. Turnbull, and D. T. Wilson, "Dyadic adaptation in business-to-business markets," European Journal of Marketing, vol. 37, no.11-12, pp.1636-1665, 2003.

[16] R. Brennan, and P. W. Turnbull, "Adaptive behavior in buyersupplier relationships," Industrial Marketing Management, vol. 28, no.5, pp. 481-495, 1999.

[17] G. J. Selig, R. LeFave, and C. V. Bullen, Implementing Strategic Sourcing, Van Haren, Publishing: NL, 2010.

[18] C. Grönroos, "The relationship marketing process: communication, interaction, dialogue, value," Journal of Business \& Industrial Marketing, vol. 19, no. 2, pp. 99-113, 2004.

[19] S. Biggemann, and F. Buttle, "Coordinated interaction and paradox in business relationships," Journal of Business \& Industrial Marketing, vol. 24, no. 8, pp. 549-560, 2009.

[20] D. Ballantyne, "Dialogue and its role in the development of relationship specific knowledge," Journal of Business \& Industrial Marketing, vol. 19, no. 2, pp. 114-123, 2004.

[21] A. Paulraj, A. A. Lado, and I. J. Chen, "Inter-organizational communication as a relational competency: Antecedents and performance outcomes in collaborative buyer-supplier relationships," Journal of Operations Management, vol. 26, no. 1, pp. 45-64, 2008.

[22] N. Capar, and M. Kotabe, "The relationship between international diversification and performance in service firms," Journal of International Business Studies, vol. 34, no. 4, pp. 345-355, 2003.

[23] J. Mohr, and J. R. Nevin, "Communication strategies in marketing channels: A theoretical perspective," The Journal of Marketing, vol. 54, no. 4, pp. 36-51, 1990

[24] K. Lindberg-Repo, "Customer relationship communication: analysing comunication from a value generating perspective," Svenska handelshögsk, 2001.

[25] A. Godfrey, K. Seiders, and G. B. Voss, "Enough is enough! The fine line in executing multichannel relational communication," Journal of Marketing, vol. 75, no. 4, pp. 94-109, 2011. 
[26] D. Gambetta, "Concatenations of mechanisms," In: P. Hedstrom and R. Swedberg Eds, Social Mechanisms: An Analytical Approach to Social Theory, Cambridge University Press: Cambridge 1998, p. 102, 1998.

[27] P. H. Andersen, and R. Kumar, "Emotions, trust and relationship development in business relationships: A conceptual model for buyer-seller dyads," Industrial marketing management, vol. 35, no.4, pp. 522-535, 2006.

[28] P. M. Doney, and J. P. Cannon, "An examination of the nature of trust in buyer-seller relationships," The Journal of Marketing, pp. 35-51, 1997.

[29] J. Srivastava, and D. Chakravarti, "Channel negotiations with information asymmetries: Contingent influences of communication and trustworthiness reputations," Journal of Marketing Research, vol. 46, no.4, pp. 557-572, 2009.

[30] Y. Grégoire, T. M. Tripp, and R. Legoux, "When customer love turns into lasting hate: the effects of relationship strength and time on customer revenge and avoidance," Journal of Marketing, vol. 73 , no. 6, pp. 18-32, 2009.

[31] R. B. Handfield, and C. Bechtel, "The role of trust and relationship structure in improving supply chain responsiveness," Industrial Marketing Management, vol. 31, no.4, pp. 367-382, 2002.

[32] S. Denize, and L. Young, "Concerning trust and information," Industrial Marketing Management, vol. 36, no.7, pp. 968-982, 2007.

[33] J. H. Dyer, and W. Chu, "The role of trustworthiness in reducing transaction costs and improving performance: Empirical evidence from the United States, Japan, and Korea," Organization Science, vol. 14 , no.1, pp. 57-68, 2003.

[34] D. Ford, and R. McDowell, "Managing business relationships by analyzing the effects and value of different actions," Industrial Marketing Management, vol. 28, no.5, pp. 429-442, 1999.

[35] K. M. Eisenhardt, and B. N. Tabrizi, "Accelerating adaptive processes: Product innovation in the global computer industry," $A D$ MINISTRATIVE SCIENCE Quarterly, 1995, pp. 84-110.

[36] C. Grönroos, and P. Voima, "Critical service logic: making sense of value creation and co-creation," Journal of the Academy of Marketing Science, vol. 41, no.2, pp. 133-150, 2013.

[37] C. Homburg, S. Kuester, and H. Krohmer, "Marketing management: A contemporary perspective," McGraw-Hill Higher Education, London, 2013.

[38] M. Kilduff, A. Mehra, and M. B. Dunn, "From blue sky research to problem solving: A philosophy of science theory of new knowledge production," Academy of Management Review, vol. 36, no.2, pp. 297-317, 2011.

[39] D. J. Flint, and J. T. Mentzer, "Striving for integrated value chain management given a service-dominant," In: R.f. Lusch and S.C. Vargo, Eds.,The Service-Dominant Logic of Marketing: Dialog, Debate, and Directions Armonk, NY: M.E. Sharpe, 2006, pp. 13949.

[40] D.G. Sirmon, M.A. Hitt, R.D. Ireland, B.A. Gilbert, "Resource orchestration to create competitive advantage breadth, depth, and life cycle effects," Journal of Management, vol. 37, no.5, pp. 1390$1412,2011$.

[41] J. J. Li, L. Poppo, and K. Z. Zhou, "Relational mechanisms, formal contracts, and local knowledge acquisition by international subsidi- aries," Strategic Management Journal, vol. 31, no.4, pp. 349-370, 2010.

[42] B. Jaworski, and A. K. Kohli, "Co-creating the voice of the customer," The Service Dominant Logic of Marketing: Dialog, Debate and Directions, pp. 109-117, 2006.

[43] R. L. Oliver, "Co-producers and co-participants in the satisfaction process: Mutually satisfying consumption," In: R. F. Lusch and S. L. Vargo, Eds, The Service Dominant Logic of Marketing: Dialog.

[44] M. Etgar, "Co-production of services: A managerial extension," In R. F. Lusch and S. L. Vargo (Eds.)," The service dominant logic of marketing: Dialog, Debate and Directions Armonk, NY: M.E. Sharpe, pp. 28-138, 2006.

[45] D. J. Flint, and J. T. Mentzer, "Striving for integrated value chain management given a service-dominant logic for marketing," In R. F. Lusch and S. L. Vargo, Eds, The service dominant logic of marketing: Dialog, Debate and Directions Armonk, NY: M.E. Sharpe, pp. 139-149, 2006.

[46] D. M. Lambert, and S. J. Garcia-Dastugue, "Cross-functional business processes for the implementation of service-dominant logic," In R. F. Lusch and S. L. Vargo, Eds, The service dominant logic of marketing: Dialog, Debate and Directions Armonk, NY: M.E. Sharpe, 2006, pp. 150-165.

[47] K. Kalaignanam, and R. Varadarajan, Customers as coproducers: Implications for marketing strategy effectiveness and marketing operations efficiency. In: R. F. Lusch, and S. L. Vargo, Eds, The Service Dominant Logic of Marketing: Dialog, Debate and Directions Armonk, NY: M.E. Sharpe, 2006, pp. 166-180.

[48] S. L. Vargo, and R. F. Lusch, "Evolving to a new dominant logic for marketing", Journal of Marketing, vol. 68, pp. 1-17, 2004.

[49] D. Ballantyne, and J. V. Richard, "Creating value-in-use through marketing interaction: The exchange logic of relating, communicating and knowing," Marketing Theory, vol. 6, no. 3, pp. 335-348, 2006.

[50] C. Fornell, and D.F. Larcker, "Evaluating structural equation models with unobservable variables and measurement error", Journal of Marketing Research, vol. 18, no. 1, pp. 39-50, 1981.

[51] R.P. Ramsey, and R.S. Sohi, "Listening to your customers: the impact of perceived salesperson listening behavior on relationship outcomes", Journal of the Academy of Marketing Sciences, vol. 25, pp. 127-37, 1997.

[52] D.M. Szymanski, and D.H. Henard, "Customer satisfaction: a meta-analysis of the empirical evidence", Journal of the Academy of Marketing Science, vol.29, no.1, pp. 16-35, 2001.

[53] A. Jamal, and K. Naser, "Customer satisfaction and retail banking: an assessment of some of the key antecedents of customer satisfaction in retail banking", International Journal of Bank Marketing, vol.20, no.4, pp. 146-60, 2002.

[54] S.D. Jap, C. Manolis, and B.A. Weitz, "Relationship quality and buyer-seller interactions in channels of distribution", Journal of Business Research, vol.46, no.3, pp. 303-13, 1999.

[55] D. T. Wilson, "An integrated model of buyer-seller relationships," Journal of the Academy of Marketing Science, vol.23, no.4, pp. $335-345,1995$. 